\title{
Successive crops of lettuce fertilized with organic compost produced from cellulose paper residues
}

\author{
Rejane Pereira de Souza ${ }^{1}$; Leidivan Almeida Frazão ${ }^{2}$; Maria das Dores Magalhães Veloso ${ }^{3}$; Regynaldo Arruda \\ Sampaio $^{4}$; Luiz Arnaldo Fernandes ${ }^{5 *}$
}

Doi: https://doi.org/10.35699/2447-6218.2021.29084

\begin{abstract}
New technologies must ensure that the natural resources used can somehow return to the environment in an advantageous way. The objective of this study was to evaluate organic compost produced from cattle manure and cellulose paper residues and lettuce production. In the organic compost the $\mathrm{Pb}$ and $\mathrm{Cd}$ concentrations were below the limits of quantification by the methodology used. The organic compost was evaluated in two consecutive lettuce crops. The first cultivation was carried out in a completely randomized design in the $4 \times 3+1$ scheme with four replicates: four doses of organic compost, three different organic compost and additional treatment, without addition of organic compost. The second cultivation was carried out 90 days after the first one, without additional of fertilizers. In the soil, there was an increase in $\mathrm{pH}, \mathrm{CEC}, \mathrm{SOC}, \mathrm{P}, \mathrm{K}, \mathrm{Ca}$ and $\mathrm{Mg}$, after 2 consecutive crops. Significative concentrations of $\mathrm{Ni}, \mathrm{Cr}$, $\mathrm{Pb}$ and $\mathrm{Cd}$ not were found in the plants in both crops. The use of organic compost from cellulose paper residues in agricultural improved soil fertility and lettuce production, being the highest yields obtained in the second crop.
\end{abstract}

Key words: Composting. Printing inks. Recycled paper.

\section{Cultivos sucessivos de alface adubada com composto orgânico de resíduos de papel}

\begin{abstract}
Resumo
As novas tecnologias devem garantir que os recursos naturais utilizados possam, de alguma forma, retornar ao meio ambiente de maneira vantajosa. O objetivo deste estudo foi avaliar a produção de compostos orgânicos produzidos a partir de esterco bovino, resíduos de papel celulósico e a produção de alface. Nos compostos orgânicos, as concentrações de $\mathrm{Pb}$ e $\mathrm{Cd}$ ficaram abaixo dos limites de quantificação do método utilizado. Os compostos orgânicos foram avaliados em dois cultivos consecutivos de alface. O primeiro cultivo foi realizado em delineamento inteiramente casualizado, no esquema $4 \times 3+1$, com quatro repetições: quatro doses de composto orgânico, três diferentes compostos orgânicos e um tratamento adicional, sem adição de composto orgânico. O segundo cultivo foi realizado 90 dias após o primeiro, sem adição de fertilizantes. No solo, a adição de compostos orgânicos aumentou o pH, CTC, COS, P, K, Ca e Mg, após 2 dois consecutivos. Não foram encontradas concentrações significativas de $\mathrm{Ni}, \mathrm{Cr}, \mathrm{Pb}$ e Cd nas plantas, nos dois. $\mathrm{O}$ uso de compostos orgânicos produzidos a partir de resíduos de papel melhorou a fertilidade do solo e a produção de alface, sendo as maiores produções obtidos no segundo cultivo.
\end{abstract}

Palavras chave: Compostagem. Resíduo de papel. Tintas para impressão.

${ }^{1}$ Universidade Federal de Minas Gerais. Montes Claros, MG. Brasil.

https://orcid.org/0000-0002-3647-9952

${ }^{2}$ Universidade Federal de Minas Gerais. Montes Claros, MG. Brasil.

https://orcid.org/0000-0001-6848-9007

${ }^{3}$ Universidade Estadual de Montes Claros. Montes Claros, MG. Brasil. https://orcid.org/0000-0002-2692-0249

${ }^{4}$ Universidade Federal de Minas Gerais. Montes Claros, MG. Brasil.. https://orcid.org/0000-0003-3214-6111

${ }^{5}$ Universidade Federal de Minas Gerais. Montes Claros, MG. Brasil.

https://orcid.org/0000-0002-9877-1924

*Autor para correspondência: luizmcmg@gmail.com

Recebido para publicação em 12 de janeiro de 2020. Aceito para publicação em 27 de janeiro de 2020 e-ISSN: 2447-6218 / ISSN: 2447-6218. Atribuição CC BY. 


\section{Introduction}

Brazil is one of the largest producers of cellulose paper in the world, being the largest in South America (Silva et al., 2010). However, the rates of paper recovery after use are still modest when compared to the rates realized by other countries. This phenomenon is linked to the lack of efficient policies and the cultural behavior of the population that has not yet incorporated sustainable habits into its routine (Gonela et al., 2015).

Composting can be used as a form of final disposal of cellulose paper residues, as long as it complies with the determinations established in the current Brazilian legislation that deals with this theme. However, when carried out in piles and with the use of a large amount of nitrogenous material, it can cause bad odors and environmental contamination. In this sense, composting in pots can be an alternative for the production of organic compounds in different environments and on a small scale.

Lettuce (Lactuca sativa L.), one of the most consumed vegetables in Brazil, can be used as a bioindicator to validate the quality of organic compost (Kiehl, 2010). The organic compost produced from cellulose paper residues may contain substances toxic to the environment, present in the inks used for printing.

Considering the scarcity of studies on the effects of organic compost produced from white and printed cellulose paper residues, the objective of this study was to evaluate organic compost produced from cattle manure and cellulose paper residues and lettuce production.

\section{Material and Methods}

The experiment was carried out in Montes Claros, Minas Gerais, Brazil (1644 '06 "S; 4351' 42” W, altitude: $648 \mathrm{~m}$ ). The climate of the region is AW type (Köppen climate classification), with an annual precipitation of approximately $1,060 \mathrm{~mm}$ and an average annual temperature of $24.20^{\circ} \mathrm{C}$. For the production of organic compost, an experiment was conducted in plastic containers with capacity of 6 liters. The experimental design was completely randomized with four treatments and eight replications. The treatments were: only cattle manure compost (CMC), cattle manure and white cellulose paper residues (edges of printed documents or parts not used for printing on documents) (CMW), cattle manure and cellulose paper residues printed with black ink and xerographic material with black ink (CMP) and fresh cattle manure (FCM) as an additional treatment (control).

The cellulose paper residues were cut into pieces of $3 \mathrm{~cm}^{2}$ and mixed with dry cattle manure in a 4:1 ratio. The initial mass of the raw materials was $1,750 \mathrm{~g}$, packed in 6 liters plastic containers: $350 \mathrm{~g}$ of cut cellulose paper and $1,400 \mathrm{~g}$ of cattle manure. The containers received water until it reached an adequate moisture, according to the "hand test" (Nunes et al., 2010). During the process, the mixture (cattle manure and cellulose paper residues) was turned over weekly for oxygenation and the moisture was controlled by weekly weighing the pots and replenishing the water when necessary. The temperature was evaluated using a dipstick thermometer.

At the end of the process (28 weeks) samples of organic compost were collected from each container to determine the $\mathrm{C} / \mathrm{N}$ ratio, $\mathrm{pH}$, nutrients, lead and cadmium concentrations (Tedesco et al., 1995).

For the study of the effects of organic compounds on soil fertility and lettuce (Lactuca sativa L.) production, two consecutive crops were carried out. The lettuce plants were growing in plastic containers filled with 3 liters of an Oxisol, collected in the superficial layer of native vegetation (Brazilian Savana). Soil characterization: $\mathrm{pH}=$ 6,3; available $\mathrm{P}=1,70 \mathrm{mg} \mathrm{kg}^{-1}$; exchangeable $\mathrm{K}=96 \mathrm{mg}$ $\mathrm{kg}^{-1}$, exchangeable $\mathrm{Ca}=2,10 \mathrm{cmolc} \mathrm{kg}^{-1}$, exchangeable $\mathrm{Mg}=1,10$ cmolc $\mathrm{kg}^{-3}$, cation exchange capacity $=4,21$ cmolc $\mathrm{kg}^{-3}$; soil organic carbon $=11,6 \mathrm{~g} \mathrm{~kg}^{-1}$.

The experimental design was completely randomized, in a factorial scheme $3 \times 4+1$, with an additional treatment and four replications, as follows: three organic fertilizers (organic compost from cattle manure, organic compost from cattle manure and white cellulose paper and organic compost from cattle manure and printed cellulose paper), four doses of organic fertilizer, equivalent to 20, 40, 80 and $160 \mathrm{Mg} \mathrm{ha}^{-1}$ and an additional treatment without the addition of organic fertilizer (Control). All treatments received a fertilization with $220 \mathrm{mg} \mathrm{dm}^{-3}$ of phosphorus in the form of single superphosphate.

For the first growing, the soil of each container was incubated with the respective treatments and the phosphate fertilizer for a period of fifteen days, keeping the moisture close to the field capacity. The lettuce seedlings were produced in Styrofoam trays and, after 30 days of sowing, two seedlings were transplanted per pot. After 30 days of growing in containers, the plants were harvested and the fresh matter production of lettuce leaves and the nutrients and heavy metals concentrations were evaluated (Malavolta et al., 1997).

To evaluate the residual effect of organic compost, a second growing lettuce was carried out at 90 days after the harvest of the plants from the first experiment, in the same containers. The conduction of the second growing was similar to that of the first. At the end of the second experiment, soil samples were collected from each container for chemical analysis (Teixeira et al., 2017).

For the organic compost experiment, the data were subjected to analysis of variance and the treatment means compared by the Scott Knott test $(\mathrm{p}<0.05)$. The data referring to the growing lettuce experiment were 
submitted to analysis of variance and the means of the additional treatment were compared with the means of organic compost by the Dunnet test $(p<5 \%)$. The means of organic compost were compared with each other by the Scott Knott test $(\mathrm{p}<5 \%)$. For the doses of organic compost, regression equations were adjusted. The statistical software used in all statistical analyzes was $\mathrm{R}$ version 3.3.0.

\section{Results and Discussion}

During the experimental period, the room temperature ranged from 26 to $37^{\circ} \mathrm{C}$, while in the mixture (cattle manure and cellulose paper residues) it ranged from 21.8 to $32.6^{\circ} \mathrm{C}$. The temperature of the mixture close to room temperature can be explained by the frequent turning of and by the low amount of nitrogen in the cellulose paper residues. Organic compost produced in small volume and with material from cellulosic origin, in general present slow degradation due to the low metabolism of the microorganisms involved in the process Kawatoko; Rizk, 2010).

Regarding moisture, at the end of the process, the fresh cattle manure had a lower moisture content than organic compost (Table 1). The organic compost from cellulose paper did not differ from each other in terms of final moisture content. The greater value for the compost produced from only cattle manure can be attributed to its composition, which retains more water than paper.

Table 1 - Chemical analysis of fresh manure (FCM), organic compost from cattle manure (CMC), organic compost from cattle manure and white cellulose paper residues (CMW) and organic compost from cattle manure and printed cellulose paper residues (CMP).

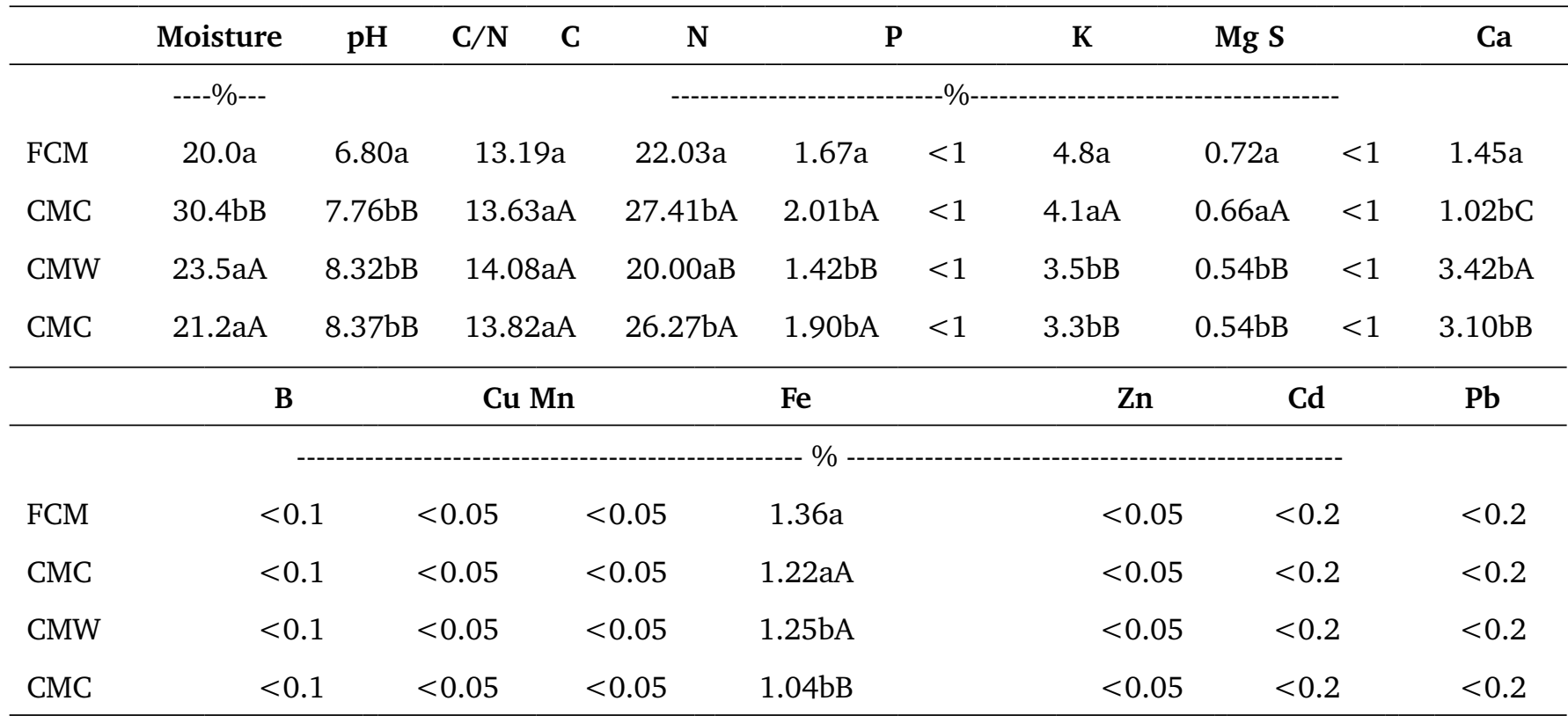

Lowercase letters in the columns compare the withnes the other treatments by the Dunnet test (p $<5 \%)$. Upper case letters in the columns compare the CMC, CMW and CMP treatments by the Scott Knott test $(\mathrm{p}<5 \%)$. Averages followed by the same letter do not differ.

The $\mathrm{pH}$ values of organic compost were higher than those of fresh cattle manure (Table 1). Raw materials with initial acid $\mathrm{pH}$ can produce organic compost with alkaline $\mathrm{pH}$ (Kiehl, 2010). According to this author, the microorganisms can use some organic acids as substrate and increases the final $\mathrm{pH}$ of the organic compost.

Regarding the composition of organic compost, the nutrient in highest concentration was $\mathrm{C}$ followed by $\mathrm{K}, \mathrm{Ca}, \mathrm{N}$ and $\mathrm{Mg}$, in that order (Table 1). All treatments showed very low concentrations of $\mathrm{P}, \mathrm{B}, \mathrm{Cu}, \mathrm{Mn}$ and $\mathrm{Zn}$, below the detection limit of the method used in this study (Table 1). For iron, fresh manure showed higher concentrations than organic compounds (Table 1). In relation to the potentially toxic metals, $\mathrm{Cd}$ and $\mathrm{Pb}$, the concentrations were below the method detection limit $\left(0.2 \mathrm{mg} \mathrm{kg}^{-1}\right)$.
For soil samples collected after the second lettuce plants harvest, it was found that the $\mathrm{pH}$, soil organic carbon (SOC), cation exchange capacity (CEC) and nutrients, except $\mathrm{N}, \mathrm{Zn}, \mathrm{Fe}, \mathrm{Ni}$ and $\mathrm{Cu}$, were higher in the treatment with organic compost (Table 2). The organic compost from cellulose paper residues provided greater CEC over time, after two lettuce plants growing, possibly due to the gradual release of carbon in the cellulose paper residues.

Regarding the doses of organic compost, it was found that the $\mathrm{pH}, \mathrm{CEC}, \mathrm{SOC}, \mathrm{Ca}, \mathrm{Mg}, \mathrm{P}$ and $\mathrm{Zn}$ values increased linearly, while there was no significant effect on the values of $\mathrm{N}, \mathrm{Ni}, \mathrm{Cu}, \mathrm{Cr}, \mathrm{Pb}$ and $\mathrm{Cd}$ (Table 3 ). Ramos et al. (2009), Abreu et al. (2010) and Cardoso et al. (2011) also found an improvement in soil fertility amendments with higher doses of organic compost after 
Souza, R. P. et al.

lettuce plants growing. Other authors point out that the amounts of nutrients made available by organic compost are proportional to the doses applied (Damatto et al., 2006; Magro et al., 2010; Cardoso et al., 2011).

Table 2 - Soil attributes and nutrient content after second lettuce crop.

\begin{tabular}{|c|c|c|c|c|c|c|c|c|}
\hline Trat. & $\mathrm{pH}$ & $\mathbf{P}$ & K & $\mathrm{Ca}$ & $\mathrm{Mg}$ & $\mathrm{T}$ & \multicolumn{2}{|c|}{ SOC } \\
\hline & & \multicolumn{2}{|c|}{------- mg kg ${ }^{-1}$------ } & \multicolumn{3}{|c|}{---------- cmolc kg ${ }^{-1}$----------- } & \multicolumn{2}{|c|}{$--\%--$} \\
\hline Control & $6.88 \mathrm{a}$ & $5.37 \mathrm{a}$ & $49.75 a$ & $2.67 \mathrm{a}$ & $1.01 \mathrm{a}$ & $4.52 \mathrm{a}$ & \multicolumn{2}{|c|}{$0.98 \mathrm{a}$} \\
\hline CMW & $7.68 \mathrm{bA}$ & $6.65 \mathrm{bB}$ & $462.56 \mathrm{bA}$ & $3.50 \mathrm{bA}$ & $1.93 \mathrm{bA}$ & 7.17bA & \multicolumn{2}{|c|}{$1.64 \mathrm{bA}$} \\
\hline CMP & $7.94 \mathrm{bA}$ & $6.96 \mathrm{bA}$ & $427.63 \mathrm{bA}$ & $3.36 \mathrm{bA}$ & $1.74 \mathrm{bB}$ & $6.75 \mathrm{bB}$ & \multicolumn{2}{|c|}{$1.68 \mathrm{bA}$} \\
\hline CMC & $7.56 \mathrm{bA}$ & 7.01bA & $388.19 \mathrm{bB}$ & $3.15 \mathrm{bA}$ & $1.54 \mathrm{bC}$ & $6.33 \mathrm{bC}$ & \multicolumn{2}{|c|}{$1.56 \mathrm{bA}$} \\
\hline Trat. & Zn & $\mathrm{Fe}$ & Mn & $\mathbf{N i}$ & $\mathrm{Cu}$ & $\mathrm{Cr}$ & $\mathrm{Pb}$ & Cd \\
\hline Trat. & \multicolumn{8}{|c|}{ - } \\
\hline Control & $6.54 \mathrm{a}$ & $70.76 a$ & 49.61 & $0.33 \mathrm{a}$ & $1.06 \mathrm{a}$ & NQ & $7.45 \mathrm{a}$ & ND \\
\hline CMW & $7.60 \mathrm{aA}$ & $51.97 \mathrm{bB}$ & 53.12 & $0.36 \mathrm{aA}$ & $0.98 \mathrm{aA}$ & $4.85 \mathrm{~A}$ & $9.68 \mathrm{bA}$ & ND \\
\hline CMP & $6.89 \mathrm{aA}$ & $53.18 \mathrm{bB}$ & 55.82 & $0.36 \mathrm{aA}$ & $1.07 \mathrm{aA}$ & $2.04 \mathrm{~B}$ & $10.18 \mathrm{bA}$ & ND \\
\hline CMC & $6.45 \mathrm{aA}$ & $63.96 \mathrm{aA}$ & 50.24 & $0.31 \mathrm{aA}$ & $0.99 \mathrm{aA}$ & NQ & $10.80 \mathrm{bA}$ & ND \\
\hline
\end{tabular}

Control; CMW = compost from cattle manure and white cellulose paper; CWP = compost from cattle manure and printed cellulose paper; CMC = compost from cattle manure. $\mathrm{NQ}=$ not quantified, $\mathrm{ND}=$ not detected. Lower case letters in the columns compare the control with the other treatments using the Dunnet test $(\mathrm{p}<5 \%)$. Capital letters in the columns compare the CMW, CMP and CMC treatments using the Scott Knott test $(\mathrm{p}<5 \%)$. The averages followed by the same letter do not differ statistically.

On the other hand, Fe and $\mathrm{K}$ values were lower at higher doses of organic compost (Table 3). For cationic micronutrients and heavy metals, immobilization by complexation reactions of these elements with humic substances present in organic compost can occur (Bezerra et al., 2009).

Table 3 - Regression equations adjusted for the soil chemical attributes after the second crop of the lettuce as a function of the different organic compost doses.

\begin{tabular}{|c|c|c|c|c|c|c|c|}
\hline Attributes & & Equation & $\mathbf{R}^{2}$ & Attributes & & Equation & $\mathbf{R}^{2}$ \\
\hline $\mathrm{pH}$ & $\begin{array}{l}\text { CMW } \\
\text { CMP } \\
\text { CMC }\end{array}$ & $\begin{array}{c}y=7.145+0.0042^{* * x} x \\
y=7.293+0.0049 * x \\
y=7.095+0.0037^{* * x}\end{array}$ & $\begin{array}{l}\mathrm{R}^{2}=0.81 \\
\mathrm{R}^{2}=0.78 \\
\mathrm{R}^{2}=0.89\end{array}$ & $\begin{array}{c}\mathrm{N} \\
(\%)\end{array}$ & $\begin{array}{l}\text { RPB } \\
\text { RPI } \\
\text { EPC }\end{array}$ & $\begin{array}{l}\mathrm{y}=0.1 \mathrm{~ns} \\
\mathrm{y}=0.1 \mathrm{~ns} \\
\mathrm{y}=0.1 \mathrm{~ns}\end{array}$ & $\begin{array}{l}- \\
- \\
-\end{array}$ \\
\hline $\begin{array}{l}\mathrm{P} \\
\left.(\mathrm{mg} \mathrm{kg})^{-1}\right)\end{array}$ & $\begin{array}{l}\text { CMW } \\
\text { CMP } \\
\text { CMC }\end{array}$ & $\begin{array}{l}y=5.082+0.0146^{* * x} x \\
y=5.882+0.0085^{* * x} x \\
y=5.281+0.0156^{* * x}\end{array}$ & $\begin{array}{l}\mathrm{R}^{2}=0.85 \\
\mathrm{R}^{2}=0.88 \\
\mathrm{R}^{2}=0.99\end{array}$ & $\begin{array}{c}\mathrm{Zn} \\
\left(\mathrm{mg} \mathrm{kg}^{-1}\right)\end{array}$ & $\begin{array}{l}\text { RPB } \\
\text { RPI } \\
\text { EPC }\end{array}$ & $\begin{array}{c}y=6.391+0.0111^{* x} \\
y=6.318+0.0077^{* x} \\
y=4.373+0.0272^{* * x}\end{array}$ & $\begin{array}{l}\mathrm{R}^{2}=0.74 \\
\mathrm{R}^{2}=0.73 \\
\mathrm{R}^{2}=0.85\end{array}$ \\
\hline $\begin{array}{l}\mathrm{K} \\
\left.(\mathrm{mg} \mathrm{kg})^{-1}\right)\end{array}$ & $\begin{array}{l}\text { CMW } \\
\text { CMP } \\
\text { CMC }\end{array}$ & $\begin{array}{c}y=17.894-4.421 * * x \\
y=76.219-4.7585^{* * x} x \\
y=29.356-3.8873^{* * x}\end{array}$ & $\begin{array}{l}\mathrm{R}^{2}=0.98 \\
\mathrm{R}^{2}=0.95 \\
\mathrm{R}^{2}=0.98\end{array}$ & $\begin{array}{c}\mathrm{Ni} \\
\left(\mathrm{mg} \mathrm{kg}^{-1}\right)\end{array}$ & $\begin{array}{l}\text { RPB } \\
\text { RPI } \\
\text { EPC }\end{array}$ & $\begin{array}{l}\mathrm{Y}=0.35 \mathrm{~ns} \\
\mathrm{Y}=0.35 \mathrm{~ns} \\
\mathrm{Y}=0.31 \mathrm{~ns}\end{array}$ & $\begin{array}{l}- \\
- \\
-\end{array}$ \\
\hline $\begin{array}{l}\mathrm{Ca} \\
\left(\mathrm{cmolc} \mathrm{kg}^{-1}\right)\end{array}$ & $\begin{array}{l}\text { CMW } \\
\text { CMP } \\
\text { CMC }\end{array}$ & $\begin{array}{l}y=2.867+0.0039 * * x \\
y=2.744+0.0034 * * x \\
y=2.744+0.0034 * * x\end{array}$ & $\begin{array}{l}\mathrm{R}^{2}=0.87 \\
\mathrm{R}^{2}=0.88 \\
\mathrm{R}^{2}=0.98\end{array}$ & $\begin{array}{c}\mathrm{Cu} \\
\left(\mathrm{mg} \mathrm{kg}^{-1}\right)\end{array}$ & $\begin{array}{l}\text { RPB } \\
\text { RPI } \\
\text { EPC }\end{array}$ & $\begin{array}{l}\mathrm{y}=0.99 \mathrm{~ns} \\
\mathrm{Y}=1.01 \mathrm{~ns} \\
\mathrm{Y}=1.01 \mathrm{~ns}\end{array}$ & $\begin{array}{l}- \\
- \\
-\end{array}$ \\
\hline $\begin{array}{l}\mathrm{Mg} \\
\left(\mathrm{cmolc} \mathrm{kg}^{-1}\right)\end{array}$ & $\begin{array}{l}\text { CMW } \\
\text { CMP } \\
\text { CMC }\end{array}$ & $\begin{array}{c}y=1.126+0.0069 * * x \\
y=1.034+0.0062 * * x \\
y=0.898+0.006 * * x\end{array}$ & $\begin{array}{l}\mathrm{R}^{2}=0.96 \\
\mathrm{R}^{2}=0.98 \\
\mathrm{R}^{2}=0.98\end{array}$ & $\begin{array}{c}\mathrm{Cr} \\
\left(\mathrm{mg} \mathrm{kg}^{-1}\right)\end{array}$ & $\begin{array}{l}\text { RPB } \\
\text { RPI } \\
\text { EPC } \\
\end{array}$ & $\begin{array}{c}\mathrm{Y}=3.88 \mathrm{~ns} \\
\mathrm{Y}=1.63 \mathrm{~ns} \\
\mathrm{ND}\end{array}$ & $\begin{array}{l}- \\
- \\
-\end{array}$ \\
\hline $\begin{array}{l}\text { CEC } \\
\left(\mathrm{cmolc} \mathrm{kg}^{-1}\right)\end{array}$ & $\begin{array}{l}\text { CMW } \\
\text { CMP } \\
\text { CMC }\end{array}$ & $\begin{array}{l}y=4.606+0.0226^{* * x} x \\
y=4.356+0.0217^{* * x} x \\
y=4.266+0.0189^{* * x} x\end{array}$ & $\begin{array}{l}\mathrm{R}^{2}=0.99 \\
\mathrm{R}^{2}=0.99 \\
\mathrm{R}^{2}=0.99\end{array}$ & $\begin{array}{c}\mathrm{Pb} \\
\left(\mathrm{mg} \mathrm{kg}^{-1}\right)\end{array}$ & $\begin{array}{l}\text { RPB } \\
\text { RPI } \\
\text { EPC }\end{array}$ & $\begin{array}{c}\mathrm{Y}=9.23 \mathrm{~ns} \\
\mathrm{Y}=9.63 \mathrm{~ns} \\
\mathrm{Y}=10.94 \mathrm{~ns}\end{array}$ & $\begin{array}{l}- \\
- \\
-\end{array}$ \\
\hline $\begin{array}{l}\text { SOC } \\
(\%)\end{array}$ & $\begin{array}{l}\text { CMW } \\
\text { CMP } \\
\text { CMC }\end{array}$ & $\begin{array}{l}y=0.873+0.0071 * * x \\
y=0.876+0.0074 * * x \\
y=0.856+0.0065^{* * x}\end{array}$ & $\begin{array}{l}\mathrm{R}^{2}=0.99 \\
\mathrm{R}^{2}=0.99 \\
\mathrm{R}^{2}=0.99\end{array}$ & $\begin{array}{c}\mathrm{Cd} \\
\left(\mathrm{mg} \mathrm{kg}^{-1}\right)\end{array}$ & $\begin{array}{l}\text { RPB } \\
\text { RPI } \\
\text { EPC }\end{array}$ & $\begin{array}{l}\text { ND } \\
\text { ND } \\
\text { ND }\end{array}$ & $\begin{array}{l}- \\
- \\
-\end{array}$ \\
\hline
\end{tabular}

$\overline{\mathrm{CMW}}=$ compost from cattle manure and white cellulose paper; $\mathrm{CWP}=$ compost from cattle manure and printed cellulose paper; CMC $=$ compost from cattle manure. $\mathrm{NQ}=$ not quantified, $\mathrm{ND}=$ not detected. 
Successive crops of lettuce fertilized with organic compost produced from cellulose paper residues

The production of fresh matter of lettuce leaves and roots, in the first harvest, was lower in the control treatment and higher in the treatment with organic compost produced from printed cellulose paper residues (Table 4). In the second harvest, the production of fresh matter in the control treatment was lower and there were no significant differences between the organic compost (Table 4).
The results obtained in the first and second crops indicate that organic compost produced from materials rich in cellulose and lignin gradually make nutrients available (Bonela et al., 2017). According to Peixoto Filho et al., 2013), for lettuce, and Lanna et al., 2018), for radish, found a greater increase in production in the second growing, due to the greater availability of nutrients over time in soils amendments with organic fertilizers.

Table 4 - Regression equations adjusted for fresh matter production of leaves and roots of lettuce plants in two consecutive crops as a function of the doses of different organic compost.

\begin{tabular}{|c|c|c|c|c|}
\hline Trat. & Equação & $\mathbf{R}^{2}$ & $\begin{array}{c}\text { Maximum pro- } \\
\text { duction. (g/ } \\
\text { plant) }\end{array}$ & $\begin{array}{l}\text { Dose for maximum pro- } \\
\left.\text { duction (Mg há }{ }^{-1}\right)\end{array}$ \\
\hline \multicolumn{5}{|c|}{ First crop } \\
\hline \multicolumn{5}{|c|}{ Fresh matter of leaves } \\
\hline CMW & $y=34.6233+0.0273^{*} x-0.0013^{*} x^{2}$ & 0.79 & 34.80 & 10.5 \\
\hline CMP & $y=26.9454+0.4075^{* * x} \mathrm{x}-0.0021^{* *} \mathrm{x}^{2}$ & 0.95 & 46.1 & 97.02 \\
\hline CMC & $\mathrm{y}=38.5832+0.0081 * \mathrm{x}-0.0015 * \mathrm{x}^{2}$ & 0.78 & 38.59 & 2.7 \\
\hline \multicolumn{5}{|c|}{ Fresh matter of roots } \\
\hline CMW & $y=17.588-0.0706^{*} x$ & 0.79 & 17.59 & 0 \\
\hline CMP & $y=14.142+0.1513 * * x-0.0008 * * x^{2}$ & 0.85 & 21.29 & 95.5 \\
\hline CMC & $y=19.969+0.0584 * * x-0.0011 * * x^{2}$ & 0.81 & 20.74 & 26.5 \\
\hline \multicolumn{5}{|c|}{ Second crop } \\
\hline \multicolumn{5}{|c|}{ Fresh matter of leaves } \\
\hline CMW & $y=28.5062+0.4793 * * x$ & 0.79 & 105.19 & 160 \\
\hline CMP & $y=26.1832+0.4628 * * x$ & 0.97 & 100.23 & 160 \\
\hline CMC & $y=30.8832+0.4473 * * x$ & 0.83 & 102.45 & 160 \\
\hline \multicolumn{5}{|c|}{ Fresh matter of roots } \\
\hline CMW & $y=18.895+0.2051 * * x-0.0026 * x^{2}$ & 0.80 & 22.94 & 39.50 \\
\hline CMP & $y=14.648+0.1275^{* * x} x-0.0007 * * x^{2}$ & 0.81 & 20.46 & 91.00 \\
\hline CMC & $y=20.475+0.0447 * * x-0.0011^{* * x^{2}}$ & 0.82 & 20.93 & 20.50 \\
\hline \multirow[t]{2}{*}{ Trat. } & \multicolumn{2}{|c|}{ Fresh matter of leaves (g/plant) } & \multicolumn{2}{|c|}{ Fresh matter of roots (g/plant) } \\
\hline & First crop $\quad$ Seconc & & First crop & Second crop \\
\hline Control & $27.50 \mathrm{a}$ & & $15.25 \mathrm{a}$ & $15.95 a$ \\
\hline CMW & $27.00 \mathrm{aB}$ & & $12.88 \mathrm{aA}$ & $23.22 \mathrm{bB}$ \\
\hline CMP & $40.06 \mathrm{bA}$ & & $17.88 \mathrm{aA}$ & $26.21 \mathrm{bA}$ \\
\hline CMC & $28.75 \mathrm{aB}$ & & $16.50 \mathrm{aA}$ & $20.53 b C$ \\
\hline
\end{tabular}

Control; CMW = compost from cattle manure and white cellulose paper; CWP = compost from cattle manure and printed cellulose paper; CMC $=$ compost from cattle manure. NQ = not quantified, ND = not detected. Lower case letters in the columns compare the control with the other treatments using the Dunnet test $(\mathrm{p}<5 \%$ ). Capital letters in the columns compare the CMW, CMP and CMC treatments using the Scott Knott test $(\mathrm{p}<5 \%)$. The averages followed by the same letter do not differ statistically

Regarding the doses of organic compost, it was verified in the first harvest that the production of fresh lettuce leaves was adjusted to a quadratic model (Table 4). In the second harvest, the production of fresh matter increased linearly with the doses of organic composts (Table 4). These results can be explained by the slow release of nutrients from organic compost and the relatively short cycle of lettuce plants (Ramos et al., 2009; Kano et al., 2011; Yagioka et al., 2014) In addition to the characteristics of the organic compost, it is important to consider the initial soil fertility. Lanna et al. (2018), studying the residual effect of the organic compost for 
Souza, R. P. et al.

radish, after the chicory harvest, found a linear increase in the production of radish plants in the highest doses of organic compost in high fertility soils, while in low fertility soils there were no significant responses to increased doses of organic compost. In this context, it can be inferred that the greater production of lettuce in the second crop can be attributed to the construction of soil fertility, once the nutrients were made available with the mineralization of organic compost over time.

According to the chemical analysis of the leaves of lettuce plants, there were few differences between treatments (Table 5).

The concentrations of N, Cu, Fe, Zn, Mn, Ni and Cr were higher in the treatments with organic compost in the first crop, while the levels of $\mathrm{P}, \mathrm{K}$ and $\mathrm{S}$ were higher in the second crop. The analysis of nutrients in the plant indicates that the increase in the dose of organic compost improved the soil CEC and favored a more balanced uptake nutrients by plants. As a consequence, the productivity of lettuce plants increased and the availability of heavy metals decreased in the second harvest, possibly due to the complexation reactions of metals with humic substances.

The results obtained in this research allow us to conclude that the organic compost improved the soil fertility and gradually made the nutrients available over time and did not present a risk of soil and plant contamination by lead and cadmium.

Table 5 - Concentrations of nutrients and metals in lettuce leaves in two consecutive crops.

\begin{tabular}{|c|c|c|c|c|c|c|c|}
\hline \multicolumn{8}{|c|}{ First crop (\%) } \\
\hline & C & $\mathbf{N}$ & $\mathbf{P}$ & $\mathbf{K}$ & $\mathrm{Ca}$ & Mg & $\mathbf{S}$ \\
\hline Control & $48.89 a$ & $3.06 \mathrm{a}$ & $0.41 \mathrm{a}$ & $2.68 \mathrm{a}$ & $0.95 a$ & $0.30 \mathrm{a}$ & $0.27 \mathrm{a}$ \\
\hline CMW & $45.43 \mathrm{aA}$ & $3.98 \mathrm{bA}$ & $0.47 \mathrm{aA}$ & $2.54 \mathrm{aA}$ & $0.76 \mathrm{bA}$ & $0.28 \mathrm{aA}$ & $0.29 \mathrm{aA}$ \\
\hline CMP & $43.70 \mathrm{aA}$ & $3.41 \mathrm{bA}$ & $0.43 a \mathrm{~A}$ & $2.56 \mathrm{aA}$ & $0.77 \mathrm{bA}$ & $0.25 \mathrm{aA}$ & $0.26 \mathrm{aA}$ \\
\hline CMC & $45.76 \mathrm{aA}$ & $3.50 \mathrm{bA}$ & $0.44 \mathrm{aA}$ & $2.77 \mathrm{aA}$ & $0.63 \mathrm{bA}$ & $0.26 \mathrm{aA}$ & $0.25 \mathrm{aA}$ \\
\hline \multicolumn{8}{|c|}{ Second crop (\%) } \\
\hline & $\mathrm{C}$ & $\mathbf{N}$ & $\mathbf{P}$ & $\mathbf{K}$ & $\mathrm{Ca}$ & Mg & $\mathbf{S}$ \\
\hline Control & $51.21 \mathrm{a}$ & $1.35 \mathrm{a}$ & $0.22 \mathrm{a}$ & $1.90 \mathrm{a}$ & $0.70 \mathrm{a}$ & $0.19 a$ & $0.16 \mathrm{a}$ \\
\hline CMW & $45.69 \mathrm{aA}$ & $2.60 \mathrm{bA}$ & $0.32 \mathrm{bA}$ & $2.73 \mathrm{bA}$ & $0.79 \mathrm{aA}$ & $0.24 \mathrm{aA}$ & $0.26 \mathrm{bA}$ \\
\hline CMP & $46.88 \mathrm{aA}$ & $2.27 \mathrm{bA}$ & $0.35 \mathrm{bA}$ & $2.56 \mathrm{bA}$ & $0.80 \mathrm{aA}$ & $0.22 \mathrm{aA}$ & $0.21 \mathrm{bA}$ \\
\hline CMC & 47.39aA & $2.46 \mathrm{bA}$ & $0.37 \mathrm{bA}$ & $2.59 \mathrm{bA}$ & $0.73 \mathrm{aA}$ & $0.24 \mathrm{aA}$ & $0.25 \mathrm{bA}$ \\
\hline
\end{tabular}

\begin{tabular}{|c|c|c|c|c|c|c|c|c|c|}
\hline \multicolumn{10}{|c|}{ First crop (\%) } \\
\hline & $\mathrm{Cu}$ & $\mathrm{Fe}$ & Zn & Mn & B & $\mathrm{Ni}$ & $\mathrm{Pb}$ & Cd & $\mathrm{Cr}$ \\
\hline Control & $3.60 \mathrm{a}$ & $186.25 a$ & $50.25 a$ & $318.90 a$ & $17.50 \mathrm{a}$ & $0.60 \mathrm{a}$ & 0 & 0 & $1.3 \mathrm{a}$ \\
\hline CMW & $4.85 \mathrm{bA}$ & 203.03bC & $39.21 \mathrm{bA}$ & $93.76 \mathrm{bB}$ & $12.57 \mathrm{aA}$ & $0.15 \mathrm{bA}$ & 0 & 0 & $0.10 \mathrm{bC}$ \\
\hline CMP & $4.58 \mathrm{bA}$ & $247.02 \mathrm{bB}$ & $33.32 \mathrm{bA}$ & $102.98 \mathrm{bB}$ & $13.60 \mathrm{aA}$ & $0.14 \mathrm{bA}$ & 0 & 0 & $0.28 \mathrm{bB}$ \\
\hline CMC & $4.74 \mathrm{bA}$ & $425.72 \mathrm{bA}$ & $34.66 \mathrm{bA}$ & $153.50 \mathrm{bA}$ & $11.48 \mathrm{aA}$ & $0.17 \mathrm{bA}$ & 0 & 0 & $0.48 \mathrm{bA}$ \\
\hline \multicolumn{10}{|c|}{ Second crop (\%) } \\
\hline & $\mathrm{Cu}$ & $\mathrm{Fe}$ & $\mathrm{Zn}$ & $\mathrm{Mn}$ & B & $\mathrm{Ni}$ & $\mathrm{Pb}$ & $\mathrm{Cd}$ & $\mathrm{Cr}$ \\
\hline Control & $1.60 \mathrm{a}$ & $89.25 a$ & $19.15 a$ & $53.00 \mathrm{a}$ & $15.75 a$ & 0.00 & 0.00 & 0.00 & 0.00 \\
\hline CMW & $2.41 \mathrm{bA}$ & $124.91 \mathrm{bA}$ & $19.55 \mathrm{aA}$ & $41.11 \mathrm{aA}$ & $16.60 \mathrm{aA}$ & 0.00 & 0.00 & 0.00 & 0.00 \\
\hline CMP & $2.43 \mathrm{bA}$ & $147.88 \mathrm{bA}$ & $19.55 \mathrm{aA}$ & $43.10 \mathrm{aA}$ & $16.59 \mathrm{aA}$ & 0.00 & 0.00 & 0.00 & 0.00 \\
\hline CMC & $2.79 \mathrm{bA}$ & $135.14 \mathrm{bA}$ & $21.53 \mathrm{aA}$ & $55.07 \mathrm{aA}$ & $18.56 \mathrm{aA}$ & 0.00 & 0.00 & 0.00 & 0.00 \\
\hline
\end{tabular}

Control; CMW = compost from cattle manure and white cellulose paper; CWP = compost from cattle manure and printed cellulose paper; CMC = compost from cattle manure. $\mathrm{NQ}=$ not quantified, ND = not detected. Lower case letters in the columns compare the control with the other treatments using the Dunnet test $(\mathrm{p}<5 \%)$. Capital letters in the columns compare the CMW, CMP and CMC treatments using the Scott Knott test $(\mathrm{p}<5 \%)$. The averages followed by the same letter do not differ statistically 


\section{Acknowledgments}

This research was supported by the National Program for Academic Cooperation of the Coordination for the Improvement of Higher Education Personnel (CAPES / Brazil), by the Brazilian National Council for Scientific and Technological Development (CNPq / Brazil) and by the Minas Gerais State Foundation for Research Support (FAPEMIG / Brazil).

\section{Conflicts of interest}

The authors declare no conflict of interest. The founding sponsors had no role in the design of the study; in the collection, analyses, or interpretation of data; in the writing of the manuscript, and in the decision to publish the results.

\section{References}

Abreu, I. M. O.; JunqueirA, A. M. R.; Peixoto, Jr; Oliveira, A. S. 2010. Qualidade microbiológica e produtividade de alface sob adubação química e orgânica. Ciência e Tecnologia de Alimentos, 30: 108-118. Doi: http://dx.doi.org/10.1590/S0101-20612010000500018.

Bezerra, P. S. S.; Takiyama, L. R.; Bezerra, C. W. B. 2009. Complexação de íons de metais por matéria orgânica dissolvida: modelagem e aplicação em sistemas reais. Acta Amazônica, 39: 639 - 648. Doi: http://dx.doi. org/10.1590/S0044-59672009000300019.

Bonela, G. D; santos, W. P.; Alves Sobrinho, E.; Gomes, E J.C. 2017. Produtividade e qualidade de raízes de rabanete cultivadas sob diferentes fontes residuais de matéria orgânica. Revista brasileira de agropecuária sustentável, 7: 66-74. Disponível em: https://www. researchgate.net/publication/317937522 PRODUTIVIDADE E QUALIDADE_DE_RAIZES_DE_RABANETE_CULTIVADAS SOBB DIFERENTES FONTES RĒSIDUAIS DE MĀTERIA ORGANICA fulltext/595 $\overline{2} 75 \mathrm{~d} 60 \mathrm{f} \overline{\mathrm{e}} \mathrm{e} 9 \mathrm{~b} 329238 \overline{1} 3 \mathrm{~b} \overline{5} / \mathrm{PRODUT}$ TIVIDADE-EQUALIDADE-DE-RAIZES-DE-RABANETE-CULTIVADAS-SOBDIFERENTES-FONTES-RESIDUAIS-DE-MATERIA-ORGANICA. pdf?origin=publication_detail.

Cardoso, A. I. I.; Ferreira, K. P; Vieira Junior, R. M. V.; Alcarde, C. 2011. Alterações em propriedades do solo adubado com composto orgânico e efeito na qualidade das sementes de alface. Horticultura Brasileira, 29: 594-599. Doi: http://dx.doi.org/10.1590/S0102-05362011000400025.

Damatto Júnior, E.R.; Villas Bôas, R. L.; Leonel, S.; Fernandes, D. M. 2006. Alterações em propriedades de solo adubado com doses de composto orgânico sob cultivo de bananeira. Revista Brasileira de Fruticultura. 28: 546-549. Doi: http://dx.doi.org/10.1590/S010029452006000300048 .

Gonela, J. S. L.; Oliveira, C. V. M.; Lamarca, D. S. F.; Braga Junior, S. S. 2015. Diagnóstico da reciclagem de papel no cenário brasileiro: uma análise quantitativa da economia de recursos naturais. ANAP Brasil, 8: 13, p.38-55. http://dx.doi.org/10.17271/1984324081320151145.

Kano, C.; Cardoso, A. I. I.; Villas Bôas, R. L. 2011. Acúmulo de nutrientes pela alface destinada à produção de sementes. Horticultura Brasileira, 29: 70-77. Doi: http://dx.doi.org/10.1590/S0102-05362011000100012.

Kawatoko, I.; Rizk, M. C. Tratamento do lodo gerado na indústria de reciclagem de papel por compostagem. Estudos Tecnológicos, 6: 68-81. Doi: http://dx.doi.org/10.4013/ete.2010.62.02.
Khiel, E. J. 2010. Novos Fertilizantes Orgânicos. 1. ed. Editora Degaspari. Piracicaba, SP.

Lanna, N. B. L.; Silva, P. N. L.; Colombari, L. F.; Corrêa, C. V.; Cardoso, A. I. I. 2018. Residual effect of organic fertilization on radish production. Horticultura Brasileira, 36: 47-53. Doi: http://dx.doi.org/10.1590/ s0102-053620180108.

Magro, F. O. et al. Composto orgânico na produção e qualidade de sementes de brócolis. Ciência e Agrotecnologia. 34: 596-6020. Doi: http://dx.doi.org/10.1590/S1413-70542010000300010.

Malavolta, E; Vitti, G. C.; Oliveira, A. S. 1997. Avaliação do estado nutricional das plantas: princípios e aplicações. 2.ed. Editora Potafós. Piracicaba, SP.

Nunes, M. U. C. 2009. Compostagem de resíduos para produção de adubo orgânico na pequena propriedade. Circular Técnica 59.

Peixoto Filho, J. U.; Freire, M. B. G. S.; Freire, F. J.; Miranda, M. F. A.; Pessoa, L. G. M.; Kamimura, K. M. 2013. Produtividade de alface com doses de esterco de frango, bovino e ovino em cultivos sucessivos. Revista Brasileira de Engenharia Agrícola e Ambiental, 17: 419-424. Doi: http://dx.doi.org/10.1590/S1415-43662013000400010.

Ramos, S. J.; Alves, D. S.; Fernandes, L. A.; Costa, C. A. 2009. Rendimento de feijão e alterações no pH e na matéria orgânica do solo em função de doses de composto de resíduo de algodão. Ciência Rural, 39: 15721576. Doi: http://dx.doi.org/10.1590/S0103-84782009005000064.

Silva, C. A. F; Bueno, J. M.; Neves, M. R. 2016. A indústria de papel e celulose no Brasil. Editora Sociedade Brasileira Técnica de Celulose e Papel. São Paulo, SP.

Tedesco, M. J.; Gianello, C.; Bissani, C. A.; Bohnen, H.; Volkweiss, S. J. Análise de solo, plantas e outros materiais. Editora UFRGS. Porto Alegre, RS.

Teixeira, P. C.; Donagemma, G. K.; Fontana, A.; Teixeira, W. G. 2017. Manual de métodos de análise de solo. 3. ed. Editora Embrapa. Brasília, DF.

Yagioka, A.; Komatsuzaki, M.; Kaneko, N. 2014. The effect of minimum tillage with weed cover mulching on organic daikon (Raphanus sativus var. longipinnatus) yield and quality and on soil carbon and nitrogen dynamics. Biological Agriculture \& Horticulture, 30: 228-242. Doi: http://dx.doi.org/10.1080/01448765.2014.922897. 